Int. J. Dev. Biol. 53: 1161-1164 (2009)

doi: $10.1387 / \mathrm{ijdb} .072313 \mathrm{jd}$

\title{
Augusto Celestino da Costa (1884-1956) - professor, scientist and science promoter
}

\author{
JOSÉ-FRANCISCO DAVID-FERREIRA* \\ Faculdade de Medicina, Universidade de Lisboa, Lisbon, Portugal
}

\begin{abstract}
At the dawn of the $20^{\text {th }}$ century in Lisbon, Augusto Celestino da Costa advocated a model of university practice based on research and defended the promotion of a scientific culture and the dissemination of Science in society. As a scientist, Celestino da Costa made numerous original descriptions of the cytology, histology and embryology of endocrine glands and the sympathetic nervous system. Celestino da Costa authored seminal textbooks on histology and embryology, and was responsible for launching in Portugal the first governmental agency to finance scientific activities.
\end{abstract}

KEY WORDS: A. Augusto Celestino da Costa, Marck Athias, medical education, histology, embryology

Despite having been world leaders in nautical technologies and maritime explorations during the 15th century, Portugal and Spain missed the scientific revolution that started in Italy in the 17th century and flourished in France, England, the Netherlands and Germany. Modem science started to emerge in both Iberian countries only during the last decades of the 19th century, when brilliant individuals like Santiago Ramon y Cajal (1852-1934) manages to break through the powerful opposition of the church to scientific and liberal ideals that flew in from abroad.

The 19th century was a golden age for European science and technical innovation, and a few Portuguese started to go abroad to study in the best Universities. Back in Portugal, they brought the youthful impetus to change and reform.

At the dawn ofthe 20th century, Augusto Celestino da Costa was a medical student in Lisbon. Admitted under exceptional circumstances to an advanced course on histology organized by Marck Athias (1875-1946), A. Celestino da Costa soon became his disciple. Marck Athias had studied Medicine in Paris and was very influenced by the ideas of Santiago Ramon y Cajal. «lt was after reading Cajal's book Les nouvelles idees sur le systeme nerveux, published in 1894, that I decided to pursue a scientific career », he said. Marck Athias was then responsible for running the Histology Laboratory created by Miguel Bombarda (1851-1910), a psychiatrist and professor at the Medical School. Miguel Bombarda was another great admirer of Cajal and leading reformist of medical studies in Lisbon. Under the supervision of Marck Athias, Celestino da Costa published his first original research article in 1904.

On the 5th of October 1910, a triumphant republican revolution ended monarchy in Portugal. Miguel Bombarda, the civil leader of the republicans, was assassinated by a psychiatric patient just a few hours before the revolution started. In 1911, at the age of 27 , Augusto Celestino da Costa was appointed professor at the Lisbon Medical School.

He was in charge of teaching histology and embryology and organizing a research laboratory. Together with his mentor Marck Athias, A. Celestino da Costa was part of a close-knit group of people upholding positivist ideals and interested in pursuing a scientific career. They advocated a model of university practice based on research and defended the promotion of a scientific culture and the dissemination of science in society. The republican victory had set the momentum for reform.

At the newly created University of Lisbon Medical School (Faculdade de Medicina), Celestino da Costa was running a stateof-the-art Histology Laboratory totally dedicated to research and practical teaching. Marck Athias had started a research programme on the histophysiology of the endocrine system and for many years the studies of Celestino da Costa were centered on the adrenal gland. The goal was to identify the cytological structures involved in hormonal activity. He reported that cells of the adrenal cortex were particularly rich in lipid inclusions (Fig. 1) and proposed that these inclusions represented the glandular product, at a time when the adrenal was not yet unanimously recognized as an endocrine gland. This interpretation was later confirmed with the demonstration that the lipid inclusions contain cholesterol esters required for the synthesis of steroid hormones secreted by the cortical cells. Celestino da Costa also described for the first time the presence of basophilic filaments in the endocrine cells of the adenohypophysis (Da Costa, 1909). He recognized these structures as equivalents

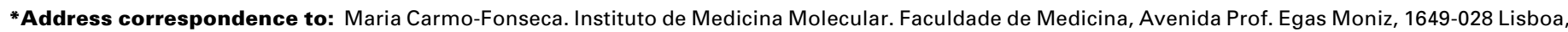
Portugal. Fax: +351-217-999-412. e-mail: carmo.fonseca@fm.ul.pt

Published online: 27 November 2008.
}

ISSN: Online 1696-3547, Print 0214-6282

(C) 2008 UBC Press

Printed in Spain 

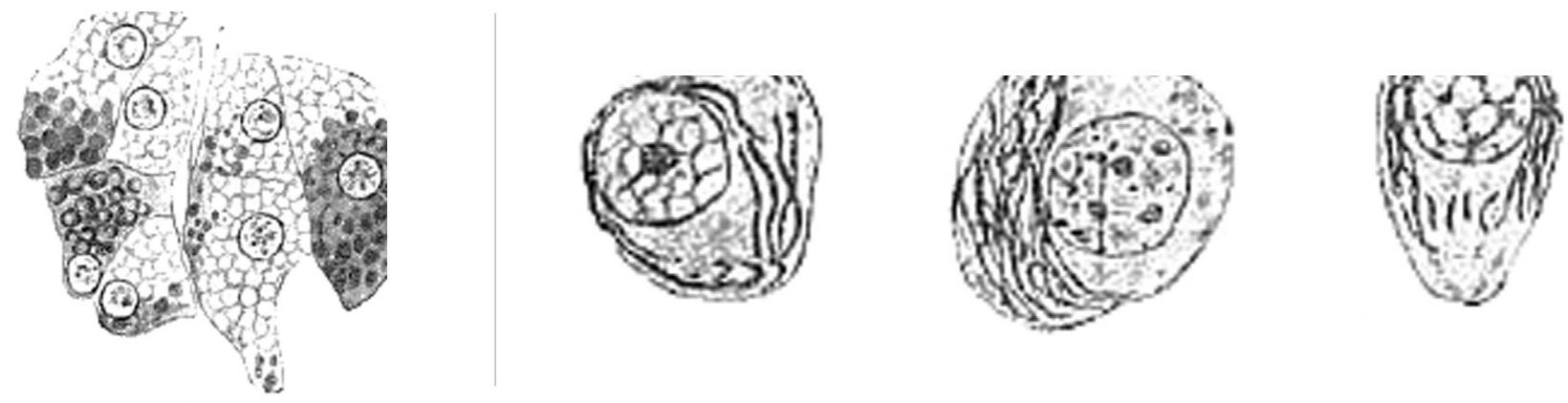

Fig. 1 (Left). Cells from the middle layer of the cat adrenal cortex. The cells are filled with spherical vacuoles resulting from extraction of the abundant lipids.

Fig. 2 (Right). Ergastoplasmic filaments in cells from the guinea pig hypophysis.

to the «ergastoplasm» described by Bouin and Garnier in pancreatic cells and proposed their involvement in endocrine glandular activity (Fig. 2). Later, he showed that basophilic filaments were detected in several types of endocrine cells and were rich in ribonucleoprotein (Da Costa et al., 1949). Subsequent electron microscopy studies demonstrated that the basophilic filaments corresponded to the rough endoplasmic reticulum, which plays a key role in all cells with secretory activity. Altogether, Celestino da Costa made numerous original descriptions of the cytology, histology and embryology of the adrenal gland that he reviewed in a book published in 1950 entitled «Le cortex surrenal».

Celestino da Costa was very rigorous in describing his observations, cautious to advance hypothesis and not reluctant to drop them when new data did not support previous interpretations. This was the case with «neurocrinia», the hypothesis that the adenohypophysis excreted products directly to the neurohypophysis. Celestino da Costa defended this theory until his own disciple, Xavier Morato (1906-1988), highlighted its incompatibility with the circulatory pathways observed in the hypophysis.

While preparing practical classes on embryology for medical undergraduates, Celestino da Costa analyzed thousands of sections from different species at different developmental stages. As mentioned in an autobiographic note, this task aroused his interest for questions related to organogenesis. In the early 20s, Celestino da Costa published original observations on the developing mammalian embryo (Fig. 3) and later he studied the origin and migration of primordial germ cells (Da Costa, 1937). Inspired by the homologies between the adrenal medulla and other neural crest derivatives, he started to investigate the origins and development of the sympathetic nervous system and the paraganglia. Because techniques to trace the migration of cells were not yet available, Celestino da Costa focused on comparative embryology. He published numerous original descriptions and review work comparing the differentiation pathways of neural crest derivatives in different species. Celestino da Costa was a remarkably gifted microscopist and cytologist (Fig. 4). Although he was never trained as an embryologist, his papers were internationally acknowledged and he was personally encouraged to pursue his studies by the reputed Belgian embryologist Albert Brachet.

The Laboratory of Celestino da Costa at the Faculdade de Medicina da Universidade de Lisboa was an attractor for medical students, including Roberto Chaves, Simoes Raposo, Dias Amado and Xavier Morato who later become professors. The school created by Celestino da Costa in Lisbon had a major impact on the development of life sciences in Portugal. Celestino da Costa and his research team were also well known and recognized abroad. He was an active member of the Association des Anatomistesand the Societe de Biologie. Out of the 27 meetings organized all over Europe by the Association des Anatomistes between 1920 and 1956, he was present in 25. At a time when traveling abroad was cumbersome, Celestino da Costa never refrained from attending international meetings and visiting research institutes throughout Europe. He published regularly his preliminary data in the Comptes Rendues de la Societe de Biologie, and he maintained regular and fraternal communication with colleagues world-wide. A particularly fruitful international collaboration that flourished under the patronage of Celestino da Costa and Gregorio Marañon were the joint meetings of the Portuguese and Spanish Endocrinology Societies, leading to the publication of a common journal (Revista Iberica de Endocrinologia).

A proficient writer, Celestino da Costa authored, in addition to a long list of scientific articles and textbooks, several manuals and

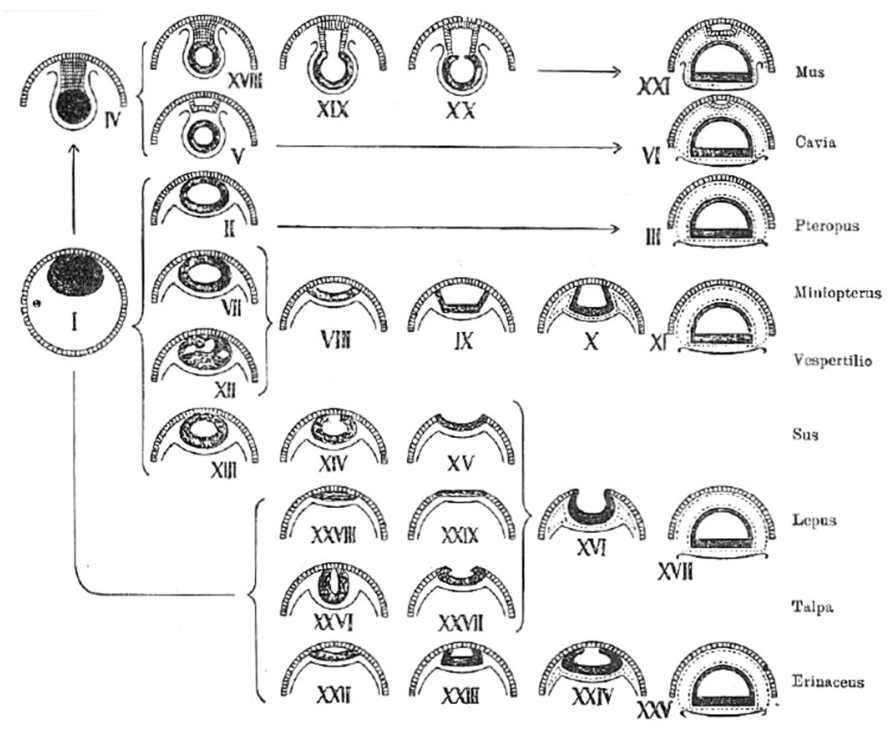

Fig. 3. Comparative embryology: amnion formation in mammals. 


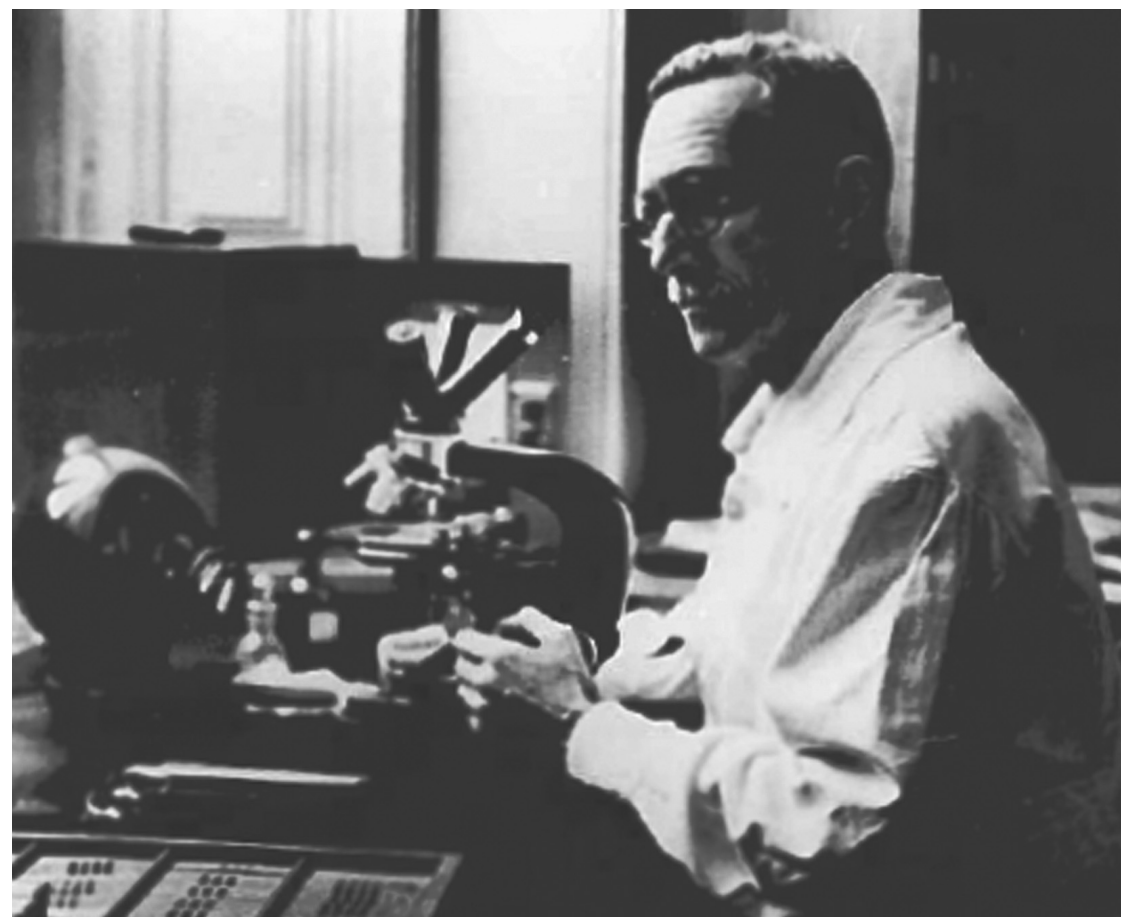

Fig. 4 (Top). Augusto Celestino da Costa working at the microscope.

Fig. 5 (Right). Augusto Celestino da Costa at the age of 60 .

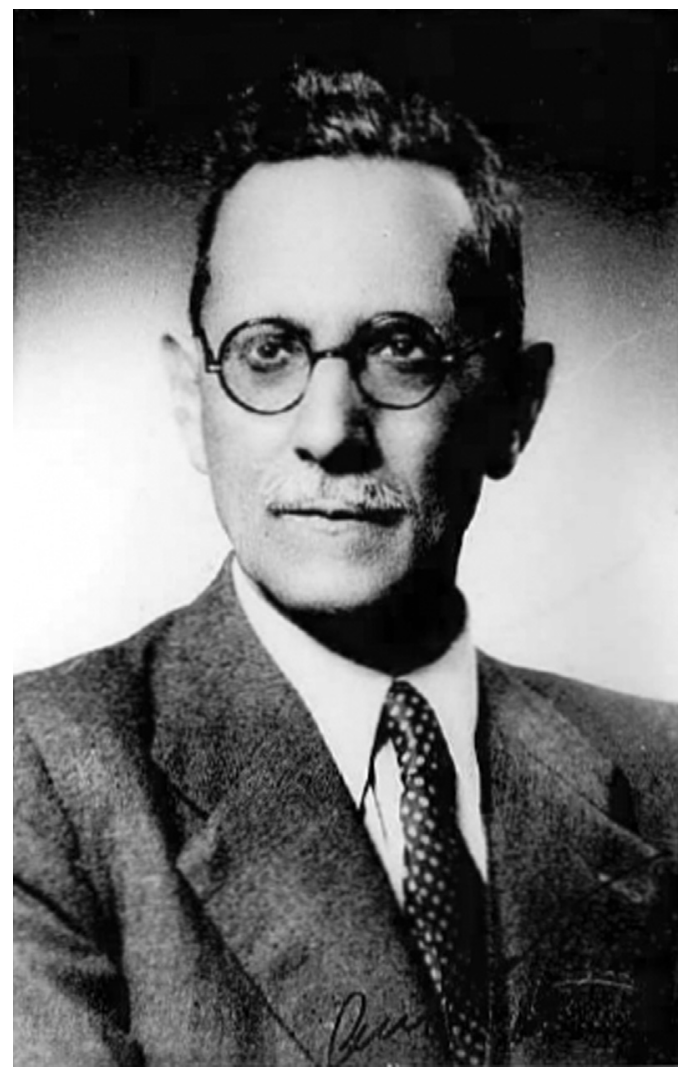

reports on medical education and the reform of the University, and dozens of historical and biographic articles. Among scientific personalities, the one most revered by Celestino da Costa was Santiago Ramon y Cajal. Celestino da Costa kept a portrait of Cajal in his office, and Cajal's book "Reglas y consejos sobre investigaccion cientifica" was obligatory reading for the scientiststo-be who joined his Laboratory.

In his autobiographic notes, Celestino da Costa mentions that one of his youth ambitions was to become a «science apostle». This was a life-long commitment. Well informed about science progress and organization throughout Europe, he presented in conferences and writings his views on the need to launch in Portugal a national agency to promote and finance scientific activities. He referred to the models introduced in countries like France, Belgium and Spain. After a long and arduous struggle he succeeded. The first governmental agency to be effective and operational was the Instituto de Alta Cultura (IAC) created in 1936. Celestino da Costa was appointed president. Despite serious budgetary constraints, he organized a national system of grants and fellowships. Funds were given to support research activities carried out within the universities; fellowships covered the training of Portuguese researchers abroad; and grants allowed the purchase of scientific equipment, books and journals, and the participation of national researchers at international meetings. Celestino da Costa had a clear vision, and his capabilities as a science organizer were well demonstrated. He was an inspired reformer and activist for scientific institutions in Portugal (Fig. 5). It all ended abruptly in 1948, when Celestino da Costa together with many other university professors were dismissed by the dictatorship of Antonio de Oliveira Salazar. Some months later he was one of the few to be re-admitted to the University, but he was not allowed to remain president of the IAC. This was a serious blow to scientific development in Portugal. During approximately three decades, the political regime instigated the exodus of scientists from the country.

With a strong will and energetic personality, Celestino da Costa never gave up when he was confronted with difficulties or adversities. His enthusiasm for scientific progress never faded out. Already after retirement, Celestino da Costa was working on a plan to wake up the national Academy of Sciences from its lethargic drowsiness. In parallel, he persisted very actively in research. He presented his last plenary lecture entitled "L 'embryologie $d u$ sympathique et de ses derives" in 1956 during the meeting of the Association des Anatomistes held in Lisbon under his presidency. It was the day before his death.

\section{Selected references}

\section{Textbooks}

DA COSTA, AC (1933) Elementos de Embriologia. I.A. Rodrigues, Lisboa. DA COSTA, AC $(1938,1948)$ Elements d'Embryologie. Masson, Paris.

DA COSTA, AC (1945) Elementos de Embriologia. Libraria Hachette, Buenos Aires. DA COSTA, AC, CHA YES, R. (1921, 1943) Manual de tecnica histológica. Lisboa. DA COSTA, AC, CHA YES, R. (1944) Tratado elementar de histologia e anatomia microscópica. Liv. Luso Espanhola, Lisboa.

DA COSTA, AC, PEIXOTO, RI (1952) Le cortex surrenal. Masson, Paris.

\section{Research articles}

DA COSTA, AC (1909). Sur lexistence de filaments ergastoplasmiques dans les cellules du lobe anterieur de l'hypophyse. Bull. Soc. Portug. Sc. Nat., III.

DA COSTA, AC (1920) Sur la formation de l'amnios chez les Cheiropteres (Miniopterus 
schreibersii) et, en general, chez les Mammiferes. Mem. Soc. Port. Sci. Nat. 3: 1 51.

DA COSTA, AC (1922) Structure et histogenese du cortex surrenal des mammiferes. Compt. Rend. Ass. Anat., XVII.

DA COSTA, AC (1937) Sur la migration des gonocytes primaires chez le cobaye. Compt. Rend. Ass. Anat., XXXII.
DA COSTA, AC (1925) Sur les images histologiques d'excretion dans le lobe posterieur de l'hypophyse. Compt. Rend. Soc. Biol., XCIl.

DA COSTA, AC, BARBA, FG, FRAZAO, $N$ (1949) Formations basophiles de nature ribonucleoproteique dans les glands endocrines. Compt. Rend. Assoc. Anat. XXXVI.

DA COSTA, AC (1956) L'embryologie du sympathique et de ses derives. Bull. Ass. Anat. 88b: 3-61.

\section{Further Related Reading, published previously in the Int. J. Dev. Biol.}

See our recent Special Issue Ear Development edited by Fernando Giraldez and Bernd Fritzsch at: http://www.ijdb.ehu.es/web/contents.php?vol=51\&issue=6-7

\section{Experimental embryology of mammals at the Jastrzebiec Institute of Genetics and Animal Breeding} Jolanta Karasiewicz and Jacek Andrzej Modlinski

Int. J. Dev. Biol. (2008) 52: 157-161

Bronislawa and Mieczyslaw Konopacki - pioneers of the application of histochemistry to embryology in Poland

Zofia Bielanska-Osuchowska

Int. J. Dev. Biol. (2008) 52: 147-150

History and status of embryology and developmental biology at Polish Medical Faculties and Schools

Hieronim Bartel

Int. J. Dev. Biol. (2008) 52: 141-146

Embryology at the Universities of Lwow and Wroclaw Antoni Ogorzalek

Int. J. Dev. Biol. (2008) 52: 135-139

Mammalian and avian embryology at Warsaw University (Poland) from XIX century to the present

Andrzej K. Tarkowski, Marek Maleszewski, Teresa Rogulska, Maria A. Ciemerych and Ewa Borsuk

Int. J. Dev. Biol. (2008) 52: 121-134

Emil Godlewski, Jr. (1875-1944) pioneer of embryology at the Jagiellonian University of Krakow (Poland)

Leopold Sliwa

Int. J. Dev. Biol. (2008) 52: 97-100

A history of normal plates, tables and stages in vertebrate embryology Nick Hopwood Int. J. Dev. Biol. (2007) 51: 1-26

First Meeting of the Portuguese Society for Developmental Biology (SPBD) Raquel P. Andrade and Leonor Saúde Int. J. Dev. Biol. (2007) 51: 177-182

Evolutionary embryology resurrected in Japan with a new molecular basis: Nori Satoh and the history of ascidian studies originating in Kyoto during the 20th century

Shigeru Kuratani, Hiroshi Wada, Rie Kusakabe And Kiyokazu Agata Int. J. Dev. Biol. (2006) 50: 451-454

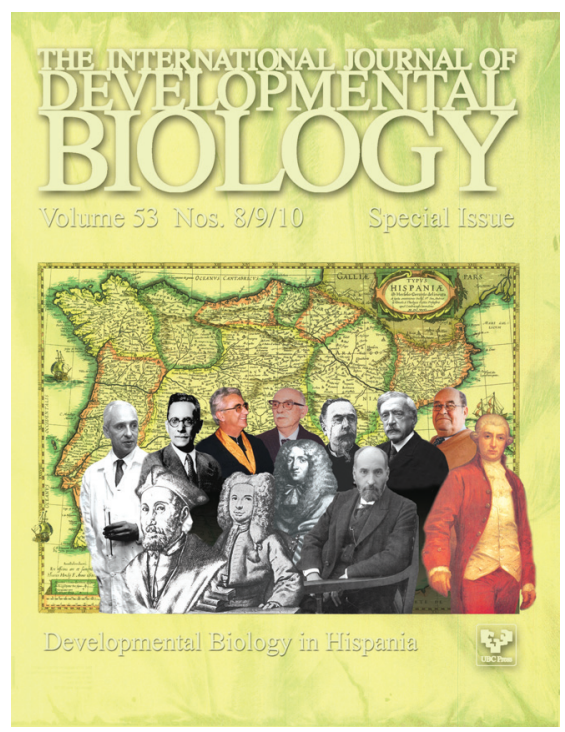

5 yr ISI Impact Factor $(2008)=3.271$

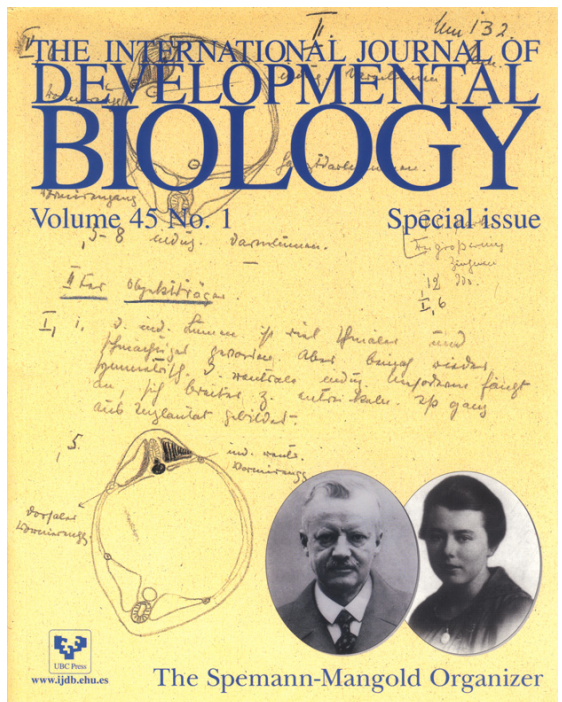

